\title{
Mixed methods study on elimination of tuberculosis in Hong Kong
}

\author{
Greta Tam *, H Yang, Tammy Meyers
}

This article was published on $27 \mathrm{Jul}$ 2018 at www.hkmj.org.

\section{A B S T R A C T}

Introduction: Tuberculosis (TB) commonly affects developing countries. Several developed regions in Asian still have a stagnant intermediate TB burden. Information to adequately inform TB strategies is lacking. We conducted a mixed methods study to fill this information gap in Hong Kong.

Methods: Data from the Hong Kong government were used to analyse trends of TB notification rates compared with World Health Organization (WHO) targets. A review of policy documents and literature was conducted to evaluate TB control and elimination in Hong Kong.

Results: Extrapolated trends showed that Hong Kong will be unable to meet the WHO target of a $90 \%$ drop in incidence rate by 2030 . The policy review showed that the Hong Kong government has not set a clear strategy and timeline for specific goals in TB control and elimination. The literature review found that older adults are largely responsible for the stagnant TB prevalence because of reactivation of latent TB infection, while mortality of hospitalised patients with $\mathrm{TB}$ is still high because of delayed diagnosis and treatment.

Conclusion: Tuberculosis incidence is currently under control in Hong Kong, but further actions are needed if the elimination targets are to be achieved. Improved diagnostic tools are required, and policies targeting latent TB infection in older adults should be implemented to achieve the WHO target by 2030 .

Hong Kong Med J 2018;24:400-7

DOI: 10.12809/hkmj177141

G Tam *, MB, BS, MS

$H$ Yang, MPH

T Meyers, MB, BS, PhD

Jockey Club School of Public Health and Primary Care, The Chinese University of Hong Kong, Shatin, Hong Kong

* Corresponding author: gretatam@cuhk.edu.hk

\section{Introduction}

Tuberculosis (TB) is a major global health burden that ranks with human immunodeficiency virus (HIV)/acquired immune deficiency syndrome (AIDS) as a leading cause of death worldwide. The World Health Organization (WHO) estimated that 9.6 million people were sickened by $\mathrm{TB}$ and 1.5 million died as a result in 2014, with 58\% of global TB cases occurring in the South-East Asia and Western Pacific regions. ${ }^{1,2}$ As a part of the global response to TB, the sixth Millennium Development Goal (MDG) set out to halve TB prevalence and mortality rates by 2015 compared with the 1990 baseline. ${ }^{3}$ Following significant declines in TB mortality and prevalence rates, in 2015, the third Sustainable Development Goals contained targets to end the epidemics of AIDS, TB, malaria, and neglected tropical disease by $2030 .{ }^{4}$ The TB target for 2030 is to reduce the number of TB deaths by 90\% compared with 2015 numbers. The WHO established the End TB Strategy in 2014, aiming to reduce the TB burden by 2030 and eliminate TB entirely by $2050 .{ }^{5,6}$ Advanced economies such as the US and Australia ${ }^{7}$ typically have low TB incidence, and TB is commonly known as a disease of poverty that more heavily affects developing countries. ${ }^{8}$ The Global Fund is conducting country case studies on
HIV/AIDS, TB, and malaria in several developing countries, including Haiti, Pakistan, and the Philippines. ${ }^{9}$ No country case studies have yet been conducted in developed Asian countries/regions such as Hong Kong, Japan, Singapore, Taiwan, or South Korea, which have good health infrastructure and stable economic growth, but where intermediate levels of TB incidence persist. ${ }^{10,11}$

Reaching the WHO targets in Asia will require strategies specific to TB epidemiology in this setting. However, information to adequately inform strategies is lacking. The last report of comparative data between Asian countries was published 10 years ago by the WHO. ${ }^{5}$ The reasons for the gap between the TB burden in Asian countries and that in their equally developed counterparts in other regions need to be understood. The ТВ burden in low-incidence countries is attributable mostly to immigrants..$^{12}$ In contrast, the stagnant intermediate incidence in developed Asian countries is ascribed mainly to latent $\mathrm{TB}$ infection in ageing populations. ${ }^{13}$

Compared with that of Singapore, Japan, or Western countries with similar gross domestic products, the notification rate of TB in Hong Kong is relatively high (60 per 100000 population in 2016). ${ }^{11,14}$ Presently, TB is the second most common notifiable disease in Hong Kong, following chickenpox. ${ }^{15}$ The 
TB notification rate in Hong Kong has declined slowly since 1995 , although the notification rate only dropped below 100 per 100000 population in 2002, and it took until 2011 for the notification rate to decline below 70 per 100000 population. ${ }^{16}$

The present case study of the TB situation in Hong Kong highlights successful policies intended to achieve WHO goals and identifies areas for further research or intervention in gaps that could prevent attainment of these targets. This could facilitate useful comparisons with the situation in other developed Asian countries.

\section{Methods}

\section{Secondary data analysis of publicly available data}

A document review including both policy and literature was conducted. Statistics on TB notification in Hong Kong were obtained from the official website of the Tuberculosis and Chest Service, Department of Health of Hong Kong SAR

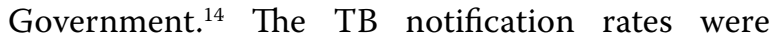
analysed in terms of immigrant status, age-group, and gender and presented in line graphs. The notification trend was extrapolated to 2030 by using Microsoft Excel's FORECAST function on the trend in the past 10 years (2005-2015).

\section{Policy review}

Existing documents from the Tuberculosis and Chest Service, Department of Health of Hong Kong SAR Government, such as the TB manual (2006), ${ }^{17}$ TB annual reports (2007-2013), ${ }^{18-24}$ information and guidelines (2006-2015), ${ }^{25-31}$ and other recommendations were obtained. Reports and strategies regarding TB control and elimination from the WHO were also reviewed to analyse how the strategy had been operationalised, how this may affect implementation of local programmes, and to identify the policy gap between the Hong Kong government's and WHO's strategies.

\section{Literature review}

Two electronic databases, PubMed and Google Scholar, were searched to identify articles related to TB control and elimination in Hong Kong. The key words 'tuberculosis' or 'TB' in combination with the terms 'Hong Kong, 'epidemiology', 'risk factors', 'prevention', 'treatment', 'Latent TB', 'MDR-TB', or 'XDR-TB' were used to search for relevant articles.

Selected publications included studies (a) carried out in Hong Kong; (b) published in the past 10 years; (c) related to $\mathrm{TB}$ prevalence, at-risk populations, and TB control measures/interventions in Hong Kong; (d) with full-text articles in English; (e) with no overlapping data; and (f) qualitative studies with sufficient sample size, significant results

\section{消除香港結核病的混合方法研究}

譚俊萱、楊華慧、邁耶斯

引言：結核病通常影響發展中國家, 但若干亞洲發達國家及地區的結 核病病發率仍屬中等水平。本文採用混合方法研究以填補目前制定結 核病控制策略訊息的不足。

方法：透過香港政府數據分析結核病呈報率的趨勢並與世界衛生組織 的所訂目標比較, 以及搜索政策回顧和文獻綜述評估香港結核病的控 制和消除策略狀況。

結果：推算趨勢表明香港在2030年前無法達到世衛將發病率降低90\% 的目標。政策回顧也顯示香港政府沒有明確的結核病控制和消除策略 及時間表。文獻綜述發現老年人的潛伏性結核病是結核病病發率仍處 一定水平的主因, 並因診斷和治療延誤使住院結核病患者的死亡率高 企。

結論：目前香港結核病的發病率已受控，惟要達到消除目標還須採取 進一步行動。要在2030年前實現世衛所訂目標, 當局須改善診斷工具 並實施針對老年群體潛伏結核感染的政策。

$(\mathrm{P}<0.05)$, and specified outcomes/outputs.

\section{Results}

\section{Tuberculosis notification in Hong Kong}

Since 1947, a downward trend in total TB notification in Hong Kong has been observed. From 1970 to 1977 , TB notification rapidly declined but remained stagnant thereafter (Fig 1). The oldest agegroup ( $\geq 75$ years) had much higher TB notification rates (Fig 2). Between 1995 and 2015, reductions in notification rates occurred in younger age-groups but increased sharply at the turn of the millennium

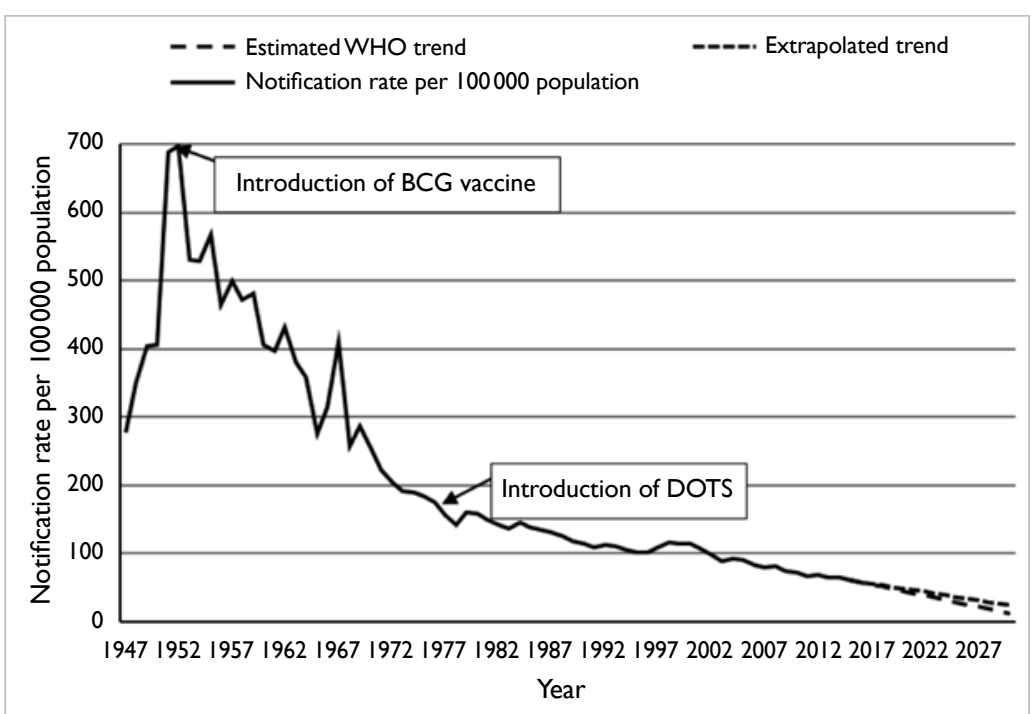

FIG I. Notification rates of TB in Hong Kong (1947-20I5) with extrapolated trend to 2030 and estimated trend according to the WHO target

Abbreviations: BCG = Bacille Calmette-Guérin; DOTS = directly observed treatment short course; $\mathrm{TB}=$ tuberculosis; $\mathrm{WHO}=$ World Health Organization 
in the oldest group, whose notification rate had only gradually decreased by 2015 . Notification rates in both genders showed downward trends, although men had a higher notification rate than women (data not shown).

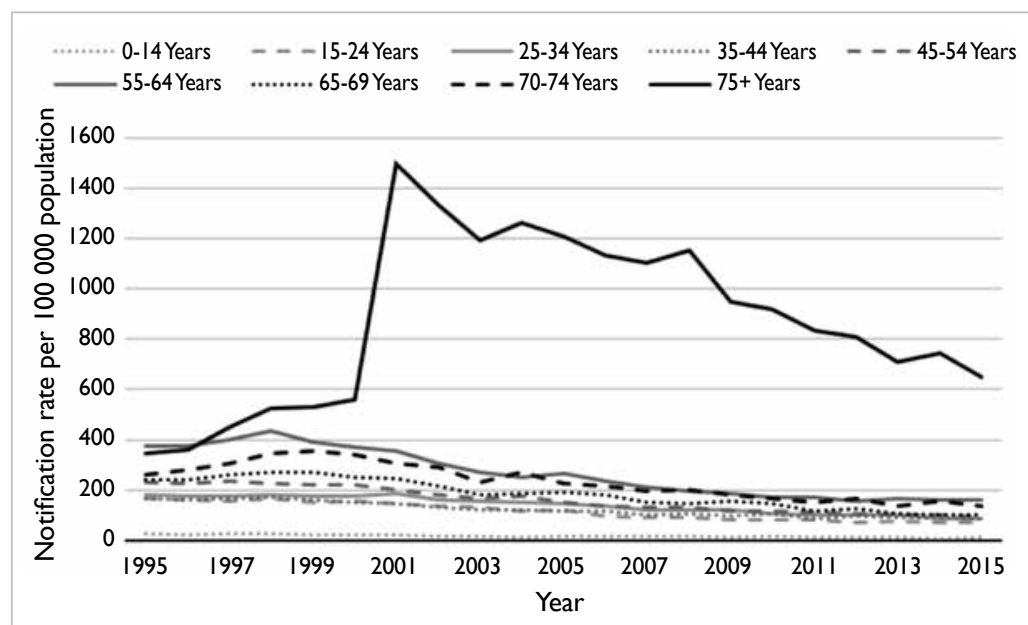

FIG 2. Notification rates of tuberculosis by age-group in Hong Kong (1995-2015)
Tuberculosis notification rates dropped rapidly after the Bacille Calmette-Guérin (BCG) vaccine was introduced in 1952, with a further decline after the introduction of directly observed treatment short course (DOTS) [Fig 1]. The incidence in 2015 had almost halved compared with that in 1990. Extrapolated trends showed that at the current rate, Hong Kong would be unable to meet the WHO target of a $90 \%$ drop in incidence rate by 2030 . By then, Hong Kong's TB notification rate is predicted to drop by only $60.2 \%$, compared with that in 2015 . The analysis shows that Hong Kong could become a low-incidence country (10 cases per 100000 population) by 2036 .

\section{Comparison of reviewed policy between the World Health Organization and Hong Kong}

A comparison between the WHO's and Hong Kong's TB policies is shown in Table $1.4,6,17,30,32,33$ In 2015, the Sustainable Development Goal 3 included a target to end the TB epidemic by $2030,{ }^{4}$ and the End TB Strategy aims to achieve a $90 \%$ drop in TB incidence rate and up to $95 \%$ reduction in number of TB-related deaths by 2035 compared with those

TABLE I. Summary of reviewed policy $4,6,17,30,32,33$

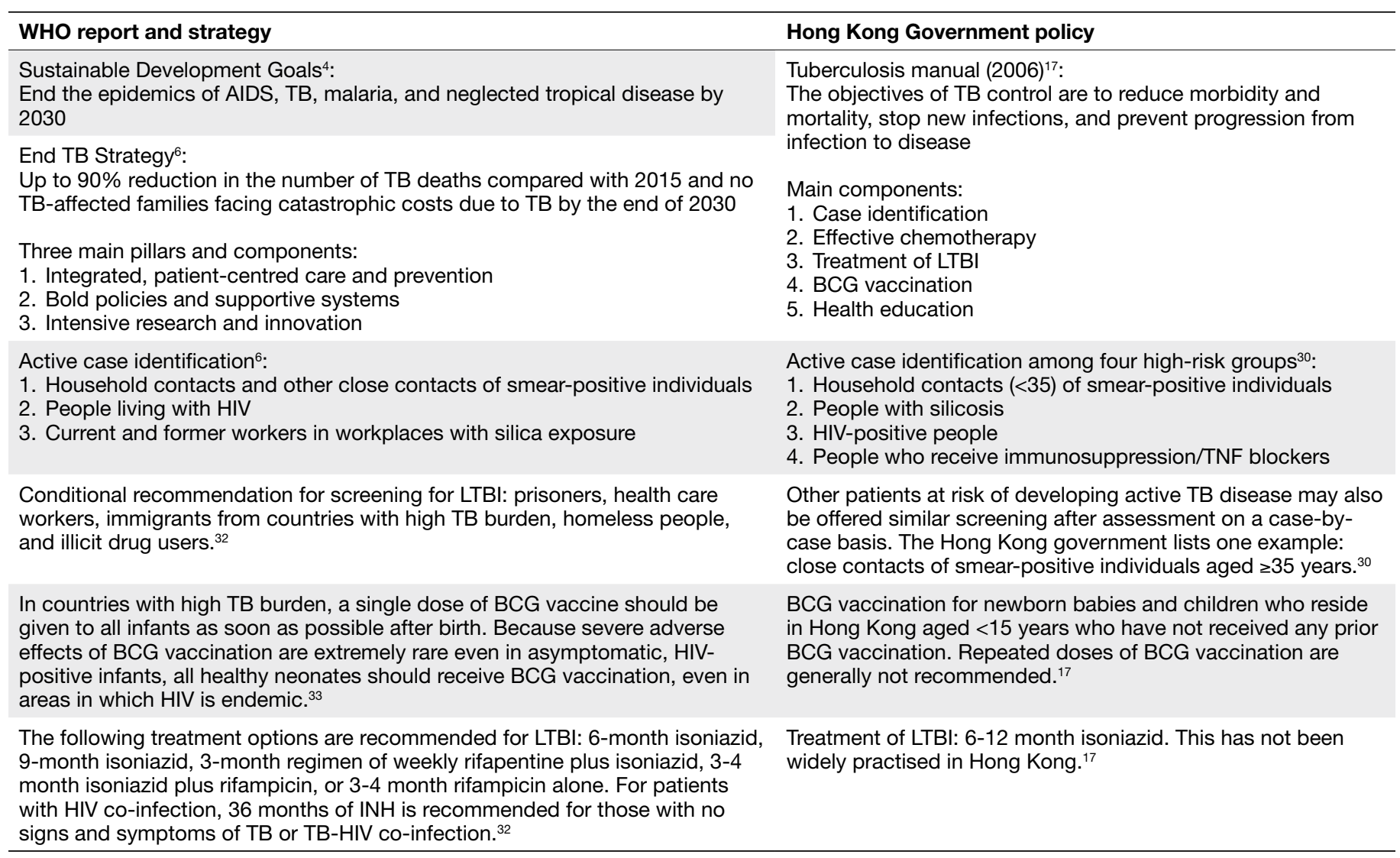

Abbreviations: AIDS = acquired immune deficiency syndrome; BCG = Bacille Calmette-Guérin; HIV = human immunodeficiency virus; INH = isonicotinylhydrazide; $\mathrm{LTBI}=$ latent tuberculosis infection; TB = tuberculosis; TNF = tumour necrosis factor; WHO = World Health Organization 
in $2015 .{ }^{6}$ Yet, the Hong Kong government has not set a clear strategy and timeline for specific goals in TB control and elimination.

The WHO guidelines for management of latent TB infection (LTBI) strongly recommended that high-income and upper-middle income countries with TB incidence less than 100 per 100000 population per year perform systematic testing and treatment of LTBI in specific groups, and Hong Kong was listed among these. ${ }^{32}$ Hong Kong follows the WHO recommendations for LTBI screening in highrisk groups. However, conditional recommendations for a number of target populations to be included in active case finding are not included in the local Hong Kong policy documents. According to the Hong Kong TB Manual, active case finding in high-risk groups was not very effective, as only $1 \%$ of active TB was found in household contacts in 2004. ${ }^{17}$

\section{Summary of reviewed literature}

We reviewed the TB literature about studies conducted in Hong Kong published in the past 10 years (Table 2). ${ }^{34-46}$ Thirteen published studies were included: two on older adults in old age homes, one on migrant populations, two on drug-resistant TB, two on HIV-related TB, two on primary school children, three on TB treatment outcomes, and one on TB prevalence in Hong Kong.

Among the included studies, three indicated that Hong Kong's TB prevalence rate is stagnating because of high TB prevalence in older adults and a high risk of $\mathrm{TB}$ reactivation ${ }^{34,35}$ caused by high prevalence of latent infection among older adults in old age homes. ${ }^{36}$ Some immigrants come from countries with higher TB incidence and drug resistance rates, particularly mainland China. These migrants may also be at increased risk of

TABLE 2. Articles on TB in Hong Kong included in the literature review ${ }^{34-46}$

\begin{tabular}{|c|c|c|c|}
\hline Study & Design & Size & Results \\
\hline Chan-Yeung et al (2006) $)^{34}$ & Cross-sectional study & 3682 & $\begin{array}{l}\text { High prevalence of LTBI is the main cause of the high rate of active } \\
\text { infection in old age homes. Early diagnosis and treatment are } \\
\text { recommended. }\end{array}$ \\
\hline Vynnycky et al (2008) ${ }^{35 *}$ & Age-structured model & - & $\begin{array}{l}\text { High prevalence of TB in older individuals and high risk of TB } \\
\text { reactivation contribute to stagnation of TB rates in Hong Kong. }\end{array}$ \\
\hline Chan-Yeung et al $(2006)^{36}$ & Cross-sectional study & 2243 & $\begin{array}{l}\text { High TB prevalence in old age homes with high risks of treatment } \\
\text { side-effects in this population. }\end{array}$ \\
\hline Leung et al $(2015)^{37}$ & Longitudinal cohort study & 5402 & $\begin{array}{l}\text { Immigrants have higher rates of TB incidence and drug resistance } \\
\text { from their place of origin. }\end{array}$ \\
\hline Wu et al $(2008)^{38 *}$ & Age-period-cohort model & - & $\begin{array}{l}\text { As the Chinese migrant population decreases, reactivation rates will } \\
\text { decrease. The effects of improved living conditions on prevalence } \\
\text { may be subject to a time lag of several decades. DOTS adherence } \\
\text { is an important determinant of TB incidence. }\end{array}$ \\
\hline Law et al $(2008)^{39}$ & Retrospective cohort study & 312 & $\begin{array}{l}\text { Movement of population and younger age were independent } \\
\text { predictors of MDR-TB in Hong Kong. }\end{array}$ \\
\hline Leung et al $(2013)^{40}$ & Retrospective cohort study & 736 & $\begin{array}{l}\text { XDR-TB increases the risk of household transmission of TB and is } \\
\text { mainly transmitted among lower-risk social contacts outside the } \\
\text { household setting in Hong Kong. }\end{array}$ \\
\hline Chan et al $(2010)^{41}$ & Retrospective cohort study & 349 & $\begin{array}{l}\text { TB the most common AIDS-defining illness in Hong Kong. LTBI } \\
\text { should be treated in patients with HIV. There is a higher rate of } \\
\text { MDR-TB in patients with HIV compared with the general population. }\end{array}$ \\
\hline Leung et al $(2016)^{42}$ & Cohort study & 478 & $\begin{array}{l}\text { The current utility of LTBI tests in patients with HIV-related TB in } \\
\text { annual screenings was doubted because of discordant rates of } \\
\text { positive results, high reversion rates, and low TB incidence. }\end{array}$ \\
\hline Leung et al (2012) ${ }^{43}$ & Prospective cohort study & 19383 & $\begin{array}{l}\text { Strong tuberculin reaction in primary school children predicted TB in } \\
\text { adolescents. }\end{array}$ \\
\hline Leung et al (2006) ${ }^{44}$ & Cohort and case-control study & 94928 & $\begin{array}{l}\text { There was a marked contrast in disease risk between those with } \\
\text { tuberculin reaction of }<15 \mathrm{~mm} \text { compared with }>15 \mathrm{~mm} \text {. In light of } \\
\text { these findings, the existing tuberculin test screening criteria may } \\
\text { need revision. }\end{array}$ \\
\hline Lui et al $(2014)^{45}$ & Retrospective cohort study & 467 & $\begin{array}{l}\text { Mortality of hospitalised patients with TB is high and new methods } \\
\text { are needed to prevent delayed diagnosis and treatment. }\end{array}$ \\
\hline Wong et al (2005) ${ }^{46}$ & Retrospective cohort study & 998 & $\begin{array}{l}\text { Patients who underwent the full course of DOTS had better } \\
\text { outcomes. Of the study's participants, } 85.6 \% \text { underwent the } \\
\text { entirety of the first } 2 \text { months. }\end{array}$ \\
\hline
\end{tabular}

Abbreviations: AIDS = acquired immune deficiency syndrome; DOTS = directly observed treatment short course; HIV = human immunodeficiency virus; $\mathrm{LTBI}=$ latent tuberculosis infection; MDR-TB = multidrug-resistant tuberculosis; TB = tuberculosis; XDR-TB = extensively drug-resistant tuberculosis

* Mathematical modelling study so no numerical sample size is included 
TB reactivation. ${ }^{37}$ However, $\mathrm{TB}$ in the migrant population is likely to decrease as migration from China is reduced and living conditions for those entering the city improve. ${ }^{38}$

Multidrug-resistant TB (MDR-TB) is a threat that is more likely in patients diagnosed with TB at younger ages. $^{39}$ Extensively drug-resistant TB (XDR-TB) significantly increases household TB transmission, demonstrating a need for prolonged household surveillance. ${ }^{40}$ Treatment of LTBI is recommended to control $\mathrm{TB}$, especially among people with HIV. Two studies reported outcomes of treating LTBI in patients with HIV in Hong Kong, one confirming the usefulness of LTBI treatment, ${ }^{41}$ while the other doubted the utility of LTBI tests in annual screening of patients with HIV because of discordant results between different tests. ${ }^{42}$ Identification of children with LTBI is also useful: in a study that described the use of tuberculin tests to screen primary school children, strong tuberculin reactions $(>15 \mathrm{~mm})$ predicted TB in adolescence. ${ }^{43,44}$ Diagnosis of TB is still problematic, and new methods are needed to prevent delayed diagnosis and treatment, ${ }^{35}$ as mortality of hospitalised TB patients is still high. ${ }^{45}$ However, one Hong Kong study demonstrated that although early diagnosis and treatment are recommended, TB therapy carried a high risk of side-effects in the study population. ${ }^{36}$ Directly observed treatment short course has significantly decreased TB incidence, ${ }^{38,46}$ although not all patients in Hong Kong completed the first 2 months of treatment, with failure to complete treatment predicting poorer outcomes than undergoing the full course. ${ }^{46}$

\section{Discussion}

In Hong Kong's older adult population, TB accounts for the majority of the city's high burden from the disease. In Hong Kong, those aged $>75$ years showed an especially high TB incidence rate. Migrants and people with HIV also have higher TB prevalence but contribute significantly less to the burden than do older adults. Children with a strong purified protein derivative reaction indicating infection were more prone to develop TB in adolescence. Also, MDR-TB and XDR-TB pose a relatively rare but important threat in Hong Kong. Late or underdiagnosis results in high TB-related mortality in those who present symptoms late and require hospitalisation.

High rates of LTBI in Hong Kong have been documented in other Asian countries with low and intermediate TB burden. ${ }^{47}$ The BCG vaccine was introduced to Hong Kong in April 1952 17 ; therefore, by 1995,2005 and 2015, those aged $>43,>53$ and $>63$ years, respectively, would not have been vaccinated in infancy. The higher prevalence of LTBI and active $\mathrm{TB}$ in old age homes compared with that in older adults living in the community is a trend shared with other countries, including low-burden countries such as the US. ${ }^{48-50}$ Despite the higher prevalence of LTBI in institutionalised older adults in Hong Kong $(68.6 \%)^{36}$ compared with their American counterparts (5.5\%), ${ }^{51-56}$ Hong Kong has not followed the US policy of LTBI testing in this population. ${ }^{57}$ Further research is needed to explore the feasibility and cost-effectiveness of screening and providing prophylaxis to older adults and other populations.

In contrast to countries with low $\mathrm{TB}$ burden, where infections in migrants primarily contribute to the burden, ${ }^{58}$ the infection rate in Hong Kong's migrant population is declining. ${ }^{16}$ However, MDR-TB rates are higher in migrants and younger age-groups in Hong Kong and countries with low TB burden. ${ }^{59,60}$ A systematic review also concurred with a Hong Kong study's findings that patients with HIV had a higher risk of MDR-TB. ${ }^{41,61}$ Meanwhile, the findings on transmission of XDR-TB in Hong Kong differ from those in Peru, where household contacts reported a very high prevalence of XDR-TB. ${ }^{62}$ It has been postulated that in Hong Kong, XDR-TB is mainly transmitted outside the household setting because of the high population density. ${ }^{40}$ The Peru study's different findings may support this idea, as the population density of Hong Kong is more than double that of Lima. ${ }^{63,64}$

The WHO has called for improved tests to diagnose LTBI, as the current ones lack accuracy. ${ }^{65}$ This was echoed by findings in the study of patients with HIV by Leung et al. $^{42}$ The finding that a strong tuberculin reaction in 6-to-10-yearold schoolchildren in Hong Kong predicted TB in adolescence was reinforced by a similar study in Singapore, which is also a developed city with an intermediate TB burden. ${ }^{43,66,67}$ However, Hong Kong schoolchildren are not routinely screened for LTBI. ${ }^{30}$ It may be advisable to extend LTBI testing to cover schoolchildren.

The high mortality of hospitalised patients with TB in Hong Kong is also seen in many other countries, ${ }^{45,68}$ emphasising the need for early detection and treatment. The DOTS strategy is an important cornerstone of TB treatment; however, there is room for improvement in compliance with DOTS in Hong Kong. ${ }^{46}$ Other developed Asian countries have similar DOTS treatment success rates to Hong Kong. ${ }^{69}$ Without improvement in medication adherence, treatment success rates are unlikely to rise.

\section{Policy recommendations}

Hong Kong reached the MDG target of reducing TB incidence, with a declining notification rate. However, according to the extrapolated trend, if improvements are not instituted, there will likely be only a $60 \%$ reduction in TB notification by 2030 compared with the 2015 baseline. To achieve the 
goal of $80 \%$ reduction in TB incidence proposed by the End TB Strategy, ${ }^{70}$ an improved supportive protocol targeting older adults with a clear timeline is needed. In addition, the Hong Kong government should consider screening high-risk groups included in the WHO's conditional recommendations. More research needs to be done to explore whether screening these groups would be beneficial.

\section{Limitations}

This study has several limitations. First, some key literature and important policies or strategies may have been missed, as no systematic review was conducted. This may have imposed error on the screening and article selection. Second, some patients that did not seek health care may have been missed by the system. Despite these limitations, this research has provided helpful suggestions and valuable insights for future research and implementation of TB-related policy.

\section{Conclusion}

The TB incidence rate is currently under control in Hong Kong, but further actions are warranted if the elimination targets are to be achieved. More accurate diagnostic tools are required, and policies targeting LTBI in older adults and children should be implemented to achieve the WHO goal by 2030 .

\section{Author contributions}

Concept or design: G Tam.

Acquisition of data: $H$ Yang.

Analysis or interpretation of data: $\mathrm{H}$ Yang.

Drafting of the article: All authors.

Critical revision for important intellectual content: G Tam, T Meyers.

\section{Funding/support}

This research received no specific grant from any funding agency in the public, commercial, or not-for-profit sectors.

\section{Declaration}

All authors have disclosed no conflicts of interest. All authors had full access to the data, contributed to the study, approved the final version for publication, and take responsibility for its accuracy and integrity. Abstract of this article was presented at Infection 2016 (13th Annual Scientific Meeting), 22 June 2016, The Chinese University of Hong Kong, Hong Kong.

\section{References}

1. World Health Organization. Tuberculosis, Fact sheet N104. Available from: http://www.who.int/mediacentre/ factsheets/fs104/en/. Accessed 11 Jul 2018.

2. World Health Organization. Global tuberculosis report 2015. Available from: http://www.who.int/tb/publications/ global_report/gtbr15_main_text.pdf. Accessed 11 Jul 2018.

3. World Health Organization. Global tuberculosis report 2014. Available from: http://www.who.int/tb/publications/ global_report/gtbr14_main_text.pdf. Accessed 11 Jul 2018.
4. World Health Organization. Health in 2015: from MDGs to SDGs. WHO report 2015. Available from: http://www. who.int/gho/publications/mdgs-sdgs/en/. Accessed $11 \mathrm{Jul}$ 2018.

5. World Health Organization. Framework towards TB elimination in low-incidence countries. 2014. Available from: http://www.who.int/tb/publications/Towards_TB_ Eliminationfactsheet.pdf. Accessed 11 Jul 2018.

6. World Health Organization. The End TB strategy; global strategy and targets for tuberculosis prevention, care and control after 2015. 2016. Available from: http://www.who. int/tb/post2015_TBstrategy.pdf. Accessed 11 Jul 2018.

7. International Monetary Fund. World economic outlook: adjusting to lower commodity prices. 2015. Available from: http://www.imf.org/external/pubs/ft/weo/2015/02/pdf/ text.pdf. Accessed 11 Jul 2018.

8. World Health Organization. Addressing poverty in TB control. Options for national TB control programmes. Available from: http://www.who.int/tb/areas-of-work/ population-groups/poverty/en/ Accessed 11 Jul 2018.

9. The Global Fund. Where we invest, The Global Fund. Available from: http://www.theglobalfund.org/en/ overview/. Accessed 11 Jul 2018.

10. The World Bank. Incidence of tuberculosis (per 100,000 people). Available from: http://data.worldbank.org/ indicator/SH.TBS.INCD. Accessed 11 Jul 2018.

11. World Health Organization. Tuberculosis (TB), tuberculosis country profiles. Available from: http://www. who.int/tb/country/data/profiles/en/. Accessed $11 \mathrm{Jul}$ 2018.

12. Pareek M, Abubakar I, White PJ, Garnett GP, Lalvani A. Tuberculosis screening of migrants to low-burden nations: insights from evaluation of UK practice. Eur Respir J 2011;37:1175-82.

13. World Health Organization. Tuberculosis control in the South-East Asia and Western Pacific regions 2005: a biregional report. Available from: http://iris.wpro.who.int/ bitstream/handle/10665.1/5519/9290611960_eng.pdf. Accessed 11 Jul 2018.

14. Tuberculosis and Chest Service, Department of Health, Hong Kong SAR Government. Statistics on tuberculosis, 2015. Available from: http://www.info.gov.hk/tb_chest/ index_2.htm. Accessed 11 Jul 2018.

15. Centre for Health Protection, Department of Health, Hong Kong SAR Government. Number of notifiable infectious disease by month in 2015, notifiable infectious disease, Statistics on communicable diseases. Available from: http://www.chp.gov.hk/en/data/1/10/26/43/3829.html. Accessed 11 Jul 2018.

16. Centre for Health Protection, Department of Health, Hong Kong SAR Government. Notification and death rate of tuberculosis (all forms), 1947-2015. Available from: http:// www.chp.gov.hk/en/data/4/10/26/43/88.html. Accessed 11 Jul 2018.

17. Tuberculosis and Chest Service, Department of Health, Hong Kong SAR Government. Tuberculosis manual 2006. 2006. Available from: http://www.info.gov.hk/tb_chest/ doc/Tuberculosis_Manual2006.pdf. Accessed 11 Jul 2018.

18. Tuberculosis and Chest Service, Department of Health, Hong Kong SAR Government. Annual report 2007. 2007. Available from: http://www.info.gov.hk/tb_chest/doc/ Annual Report 2007.pdf. Accessed 11 Jul 2018.

19. Tuberculosis and Chest Service, Department of Health, 
Hong Kong SAR Government. Annual report 2008. 2008. Available from: http://www.info.gov.hk/tb_chest/doc/ Annual_Report_2008.pdf. Accessed 11 Jul 2018.

20. Tuberculosis and Chest Service, Department of Health, Hong Kong SAR Government. Annual report 2009. 2009. Available from: http://www.info.gov.hk/tb_chest/doc/ AnnualReport2009.pdf. Accessed 11 Jul 2018.

21. Tuberculosis and Chest Service, Department of Health, Hong Kong SAR Government. Annual report 2010. 2010. Available from: http://www.info.gov.hk/tb_chest/doc/ AnnualReport2010.pdf. Accessed 11 Jul 2018.

22. Tuberculosis and Chest Service, Department of Health, Hong Kong SAR Government. Annual report 2011. 2011. Available from: http://www.info.gov.hk/tb_chest/doc/ AnnualReport2011.pdf. Accessed 11 Jul 2018.

23. Tuberculosis and Chest Service, Department of Health, Hong Kong SAR Government. Annual report 2012. 2012. Available from: http://www.info.gov.hk/tb_chest/doc/ AnnualReport2012.pdf. Accessed 11 Jul 2018.

24. Tuberculosis and Chest Service, Department of Health, Hong Kong SAR Government. Annual report 2013. 2013. Available from: http://www.info.gov.hk/tb_chest/doc/ AnnualReport2013.pdf. Accessed 11 Jul 2018.

25. Tuberculosis and Chest Service, Department of Health, Hong Kong SAR Government. Recommendations on the management of human immunodeficiency virus and tuberculosis coinfection. 2008. Available from: http://www. chp.gov.hk/files/pdf/recommendations_on_management of_human_immunodeficiency_virus_and_tuberculosis_ coinfection_r.pdf. Accessed 11 Jul 2018.

26. Tuberculosis and Chest Service, Department of Health, Hong Kong SAR Government. Guidelines on the management of multidrug-resistant and extensively drugresistant tuberculosis in Hong Kong. 2008. Available from: http://www.info.gov.hk/tb_chest/doc/MDRTB guideline_0812.pdf. Accessed 11 Jul 2018.

27. Centre for Health Protection, Department of Health, Hong Kong SAR Government. The use of BCG vaccine in HIV infected patients. 2009. Available from: http://www. chp.gov.hk/files/pdf/the_use_of_bcg_vaccine_in_hiv_ infected_patients_r.pdf. Accessed 11 Jul 2018

28. Tuberculosis and Chest Service, Department of Health, Hong Kong SAR Government. Ambulatory treatment and public health measures for a patient with uncomplicated pulmonary tuberculosis-an information paper. 2013. Available from: http://www.info.gov.hk/tb_chest/doc/ Information_paper_ambulatory_tb_2013.pdf. Accessed 11 Jul 2018.

29. Tuberculosis and Chest Service, Department of Health, Hong Kong SAR Government. Guidance on logistical arrangement for targeted screening and treatment of latent tuberculosis infection among immunocompetent household contacts of smear-positive pulmonary tuberculosis patients in TB and Chest Service. 2013. Available from: http://www.info.gov.hk/tb_chest/doc/ Guidance_Notes_Contact_TBCS_upated 1 NOV 2013. pdf. Accessed 11 Jul 2018.

30. Tuberculosis and Chest Service, Department of Health, Hong Kong SAR Government. Guidelines on targeted tuberculin testing and treatment of latent tuberculosis infection. 2015. Available from: http://www.info.gov.hk/ tb_chest/doc/LTBI_guide_TBCS_2012_update 1 Nov2013 _ADD_31March2015.pdf. Accessed 11 Jul 2018.
31. Tuberculosis and Chest Service, Department of Health, Hong Kong SAR Government. Scheme for investigation of close contacts (household) in the Tuberculosis \& Chest Service, Department of Health. 2015. Available from: http:// www.info.gov.hk/tb_chest/doc/TST_contacts of smearnegative sources.pdf. Accessed 11 Jul 2018.

32. Getahun H, Matteelli A, Abubakar I, et al. Management of latent mycobacterium tuberculosis infection: WHO guidelines for low tuberculosis burden countries. Eur Respir J 2015;46:1563-76.

33. World Health Organization. Weekly epidemiological record. 2004. Available from: http://www.who.int/ wer/2004/en/wer7904.pdf?ua=1. Accessed 11 Jul 2018.

34. Chan-Yeung M, Cheung AH, Dai DL, et al. Prevalence and determinants of positive tuberculin reactions of residents in old age homes in Hong Kong. Int J Tuberc Lung Dis 2006;10:892-8.

35. Vynnycky E, Borgdorff MW, Leung CC, Tam CM, Fine PE. Limited impact of tuberculosis control in Hong Kong: attributable to high risks of reactivation disease. Epidemiol Infect 2008;136:943-52.

36. Chan-Yeung M, Chan FH, Cheung AH, et al. Prevalence of tuberculous infection and active tuberculosis in old age homes in Hong Kong. J Am Geriatr Soc 2006;54:1334-40.

37. Leung $\mathrm{CC}$, Chan $\mathrm{CK}$, Chang $\mathrm{KC}$, et al. Immigrants and tuberculosis in Hong Kong. Hong Kong Med J 2015;21:31826.

38. Wu P, Cowling BJ, Schooling CM, et al. Age-period-cohort analysis of tuberculosis notifications in Hong Kong from 1961 to 2005. Thorax 2008;63:312-6.

39. Law WS, Yew WW, Chiu Leung C, et al. Risk factors for multidrug-resistant tuberculosis in Hong Kong. Int J Tuberc Lung Dis 2008;12:1065-70.

40. Leung EC, Leung CC, Kam KM, et al. Transmission of multidrug-resistant and extensively drug-resistant tuberculosis in a metropolitan city. Eur Respir J 2013;41:901-8.

41. Chan CK, Alvarez Bognar F, Wong $\mathrm{KH}$, et al. The epidemiology and clinical manifestations of human immunodeficiency virus-associated tuberculosis in Hong Kong. Hong Kong Med J 2010;16:192-8.

42. Leung CC, Chan K, Yam WC, et al. Poor agreement between diagnostic tests for latent tuberculosis infection among HIV-infected persons in Hong Kong. Respirology 2016;21:1322-9.

43. Leung CC, Yew WW, Au KF, et al. A strong tuberculin reaction in primary school children predicts tuberculosis in adolescence. Pediatr Infect Dis J 2012;31:150-3.

44. Leung CC, Yew WW, Chang KC, et al. Risk of active tuberculosis among schoolchildren in Hong Kong. Arch Pediatr Adolesc Med 2006;160:247-51.

45. Lui G, Wong RY, Li F, et al. High mortality in adults hospitalized for active tuberculosis in a low HIV prevalence setting. PLoS One 2014;9:e92077.

46. Wong MY, Leung CC, Tam CM, Lee SN. Directly observed treatment of tuberculosis in Hong Kong. Int J Tuberc Lung Dis 2005;9:443-9.

47. Mori T, Leung CC. Tuberculosis in the global aging population. Infect Dis Clin North Am 2010;24:751-68.

48. Stead WW, Dutt AK. Tuberculosis in elderly persons. Annu Rev Med 1991;42:267-76.

49. Stead WW, Lofgren JP, Warren E, Thomas C. Tuberculosis as an endemic and nosocomial infection among the elderly 
in nursing homes. N Engl J Med 1985;312:1483-7.

50. Macarthur C, Enarson DA, Fanning EA, Hessel PA, Newman S. Tuberculosis among institutionalized elderly in Alberta, Canada. Int J Epidemiol 1992;21:1175-9.

51. Shea KM, Kammerer JS, Winston CA, Navin TR, Horsburgh CR Jr. Estimated rate of reactivation of latent tuberculosis infection in the United States, overall and by population subgroup. Am J Epidemiol 2014;179:216-25.

52. Welty C, Burstin S, Muspratt S, Tager IB. Epidemiology of tuberculous infection in a chronic care population. Am Rev Respir Dis 1985;132:133-6.

53. Dorken E, Grzybowski S, Allen EA. Significance of the tuberculin test in the elderly. Chest 1987;92:237-40.

54. Stead WW, To T. The significance of the tuberculin skin test in elderly persons. Ann Intern Med 1987;107:837-42.

55. Nisar M, Williams CS, Ashby D, Davies PD. Tuberculin testing in residential homes for the elderly. Thorax 1993;48:1257-60.

56. Creditor MC, Smith EC, Gallai JB, Baumann M, Nelson KE. Tuberculosis, tuberculin reactivity, and delayed cutaneous hypersensitivity in nursing home residents. J Gerontol 1988;43:M97-100.

57. Centers for Disease Control and Prevention. Latent tuberculosis infection: a guide for primary health care providers. 2013. Available from: http://www.cdc.gov/tb/ publications/ltbi/targetedtesting.htm. Accessed $11 \mathrm{Jul}$ 2018.

58. Pareek M, Greenaway C, Noori T, Munoz J, Zenner D. The impact of migration on tuberculosis epidemiology and control in high-income countries: a review. BMC Med 2016;14:48.

59. Hargreaves S, Lönnroth K, Nellums LB, et al. Multidrugresistant tuberculosis and migration to Europe. Clin Microbiol Infect 2017;23:141-6.

60. Faustini A, Hall AJ, Perucci CA. Risk factors for multidrug resistant tuberculosis in Europe: a systematic review. Thorax 2006;61:158-63.

61. Mesfin YM, Hailemariam D, Biadgilign S, Kibret KT. Association between HIV/AIDS and multi-drug resistance tuberculosis: a systematic review and meta-analysis. PLoS One 2014;9:e82235.

62. Becerra MC, Appleton SC, Franke MF, et al. Tuberculosis burden in households of patients with multidrug-resistant and extensively drug-resistant tuberculosis: a retrospective cohort study. Lancet 2011;377:147-52.

63. World population review. Lima population 2017. 2018. Available from: http://worldpopulationreview.com/worldcities/lima-population/. Accessed 11 Jul 2018.

64. World population review. Hong Kong population 2017. 2018. Available from: http://worldpopulationreview.com/ countries/hong-kong-population/\#. Accessed 11 Jul 2018.

65. World Health Organization. WHO guidelines on the management of latent tuberculosis infection launched today. Available from: http://www.who.int/tb/features_ archive/LTBI/en/. Accessed 11 Jul 2018.

66. Chee CB, Soh CH, Boudville IC, Chor SS, Wang YT. Interpretation of the tuberculin skin test in Mycobacterium bovis BCG-vaccinated Singaporean schoolchildren. Am J Respir Crit Care Med 2001;164:958-61.

67. World Health Organization. Tuberculosis. 2007. Available from: http://www.wpro.who.int/mediacentre/factsheets/ fs_20060829/en/. Accessed 11 Jul 2018.

68. Waitt CJ, Squire SB. A systematic review of risk factors for death in adults during and after tuberculosis treatment. Int J Tuberc Lung Dis 2011;15:871-85.

69. Tam CM. The DOTS strategy in Hong Kong. Med Bull 2006;11:3-4.

70. World Health Organization. The End TB Strategy. Available from: http://www.who.int/tb/End_TB_brochure.pdf?ua $=1$. Accessed 11 Jul 2018. 